\title{
Malignant Ovarian Steroid Cell Tumor, Not Otherwise Specified, Causes Virilization in a 4-Year-Old Girl: A Case Report and Literature Review
}

\author{
Takaharu Yoshimatsu $^{a}$ Kozo Nagai ${ }^{a}$ Reiji Miyawaki ${ }^{a}$ Kyoko Moritani ${ }^{a}$ \\ Kazuhiro Ohkubo a, b Jun Kuwabarac Kyosuke Tatsutac Mie Kuratad, e \\ Mana Fukushima $^{f}$ Riko Kitazawa ${ }^{f}$ Junpei Hamada ${ }^{a}$ Fumihiro Ochia \\ Minenori Eguchi-Ishimae ${ }^{a}$ Hisamichi Tauchia Mariko Eguchi ${ }^{a}$

\begin{abstract}
aDepartment of Pediatrics, Ehime University Graduate School of Medicine, Toon, Japan; ${ }^{b}$ Department of Community and Emergency Medicine, Ehime University Graduate School of Medicine, Toon, Japan; 'Department of Pediatric Surgery, Ehime University Graduate School

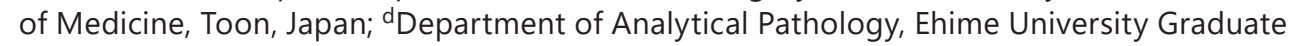
School of Medicine, Toon, Japan; eProteoscience Center Division of Pathology, Ehime University Graduate School of Medicine, Toon, Japan; fDivision of Diagnostic Pathology, Ehime University Hospital, Toon, Japan
\end{abstract}

\section{Keywords}

Steroid cell tumor · Not otherwise specified · Child · Ovary · Chemotherapy

\begin{abstract}
We report a case of a 4-year-old girl with an ovarian steroid cell tumor, not otherwise specified (SCT-NOS). She was admitted to the hospital with progressing virilization and Cushing's syndrome, which included abnormality of the perineum, hirsutism, hypertrichosis, flushing of face, hoarseness, and weight gain. Blood testing showed a significantly increased testosterone level and slightly increased cortisol level. Computed tomography scan revealed an $8.0 \times$ $5.0 \times 5.0 \mathrm{~cm}$ tumor of the right ovary. The patient underwent right salpingo-oophorectomy, and pathological examination showed malignant potential. Three courses of bleomycin, etoposide, and cisplatin were administered as postoperative chemotherapy. After tumor resection, her testosterone decreased to undetectable levels. However, during the course of the treatment, the patient suffered from adrenal insufficiency resulting in the need for hydrocortisone replacement therapy. Although SCT-NOS in childhood are typically benign, pathological findings should be carefully observed for potential malignancy. In cases of cortisol-producing SCT-NOS, serum levels should be monitored, and hydrocortisone replacement therapy should be considered before resection.




\section{Introduction}

Ovarian tumors comprise approximately $1 \%$ of all childhood cancers [1]. Most ovarian tumors in children are benign mature or immature teratomas. Ovarian neoplasms in children are rare and comprise $0.1 \%$ of all ovarian tumors. Ovarian sex cord-stromal tumors (SCST), which are distinct from germ cell tumors and epithelial ovarian tumors, comprise approximately $7 \%$ of ovarian tumors overall and approximately $15 \%$ of ovarian tumors in children. According to their cell of origin, these tumors have been divided into three subtypes: stromal luteomas, Leydig cell tumors, and steroid cell tumors, not otherwise specified (SCT-NOS) [2]. This category of tumor accounts for only $1.3-2.3 \%$ of SCST and can occur at any age, although the mean age of occurrence is 43 years [2]. SCT-NOS in children and adolescents are extremely rare, with only about 9 cases found in a PubMed search [2-11]. In some pediatric SCT-NOS cases, the functional features of steroid hormone-secreting cells produce characteristic clinical signs of virilization and Cushing's syndrome. The majority of these tumors have a benign character, but a small portion of them behave in a malignant manner.

In this report, we describe the case of a 4-year-old girl who presented with typical symptoms of SCT-NOS before puberty: abnormal height growth, virilization, and hirsutism. All reported pediatric cases of SCT-NOS have been benign in character; however, histopathological studies in this case revealed malignant features, resulting in the decision to administer postoperative chemotherapy [2-11]. SCT-NOS of the ovary should be considered in cases of childhood virilization. In addition, treatment for this tumor type and follow-up regarding endocrinological symptoms are further explained in the Discussion section.

\section{Case Report}

A 4-year-old female patient was admitted to our hospital with abdominal distention, hoarseness associated with virilization, hirsutism (Fig. 1A and B), cliteromegaly, and the characteristic moon face and facial flushing signs of Cushing's syndrome (Fig. 1C). The patient had unremarkable anamnesis and a negative family history.

Her weight had increased by $3.8 \mathrm{~kg}$ over the previous 3 months, but her height had increased by only $2.0 \mathrm{~cm}$ during the same period. A skeletal bone age of around chronological age +3 years was recognized.

Abdominal ultrasonography detected an $80 \times 50 \times 50 \mathrm{~mm}$ tumor of the right ovary (Fig. 1D). CT pelvic scan and MRI revealed a fat-containing bimodal pelvic mass (Fig. 1E). PET-CT showed no metastatic lesions.

Blood test showed a serum testosterone level of $242.3 \mathrm{ng} / \mathrm{dL}$, a blood cortisol concentration of $21.5 \mu \mathrm{g} / \mathrm{dL}$ (daytime collection), an adrenocorticotropic hormone concentration that was inhibited to $1.4 \mathrm{pg} / \mathrm{mL}$, and an aldosterone concentration within normal range. There were no luteinizing hormone or follicle-stimulating hormone abnormalities. Besides a lactate dehydrogenase level of $364 \mathrm{U} / \mathrm{L}$ and a neuron-specific enolase level of $36.6 \mathrm{ng} / \mathrm{mL}$, an increase in other tumor markers was absent.

The patient then underwent right salpingo-oophorectomy. The surface of the tumor was smooth and white without adhesion to the surrounding area (Fig. 2A and B) and was found to originate from the right ovary. Her left ovary was normal, and peritoneal dissemination was not seen on intraoperative findings. Cytologic testing of ascites was negative for tumor cells. On pathological examination, clear-type cells with rich transparent cytoplasm, visible large vacuole formation, and small nuclei were diffusely proliferated in the adrenal cortex (Fig. 2C). Three nuclear divisions were observed in 10 high-power fields (HPF), and nuclear dysplasia was occasionally detected (Fig. 2D). The fibrous capsule was maintained, but tumor 

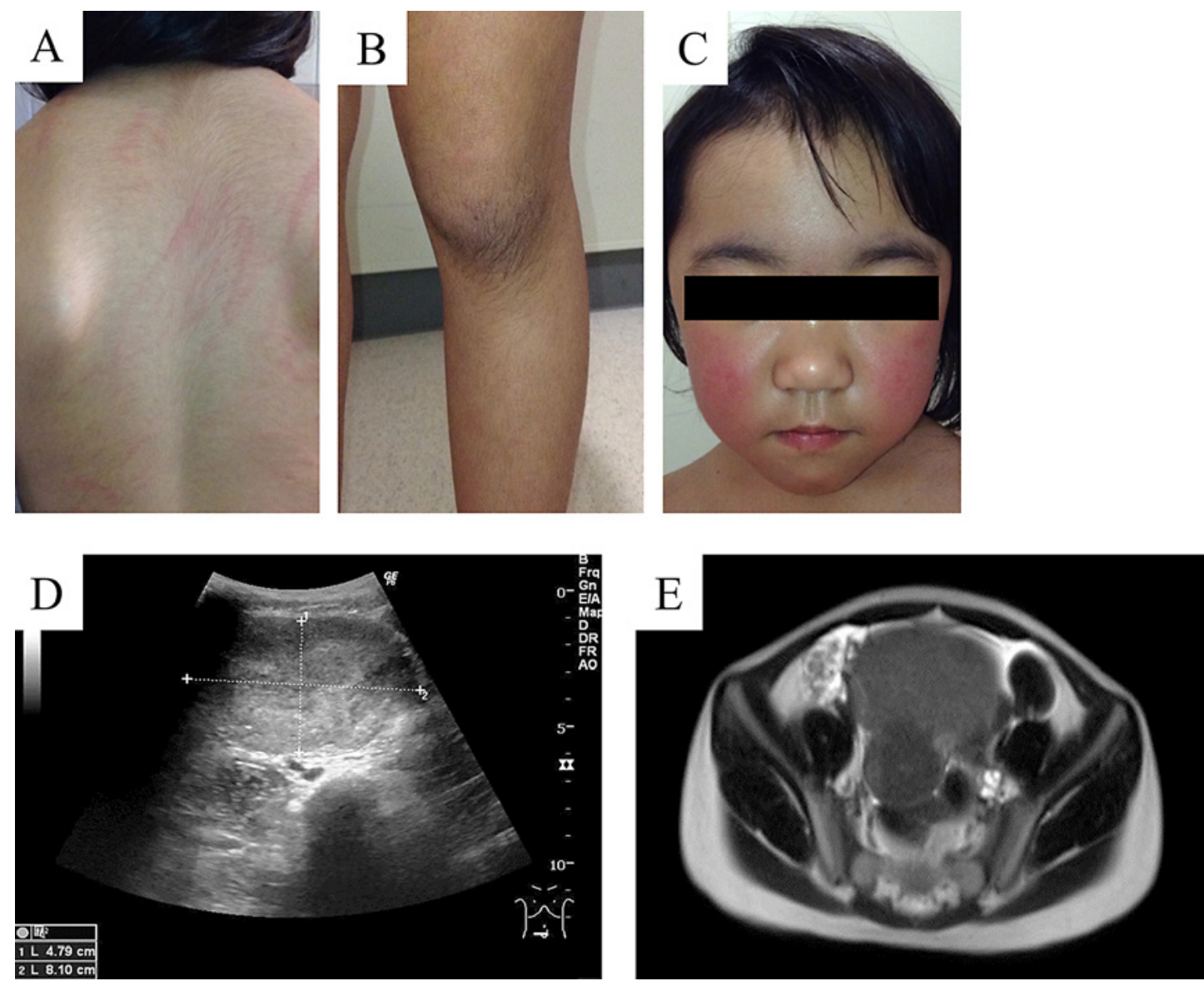

Fig. 1. Clinical and imaging findings for our ovarian tumor patient. Photographs show hairiness of the neck, back (A), and knee (B). Moon face and facial flushing appeared as signs of Cushing's syndrome (C). Abdominal ultrasonography revealed an 8.0-cm-sized well-defined uniform solid tumor (D). Dual absorption areas in the tumor were observed by CT (E). The tumor was uniformly visualized on T2-weighted magnetic resonance imaging $(\mathbf{F})$.

cells were infiltrating into the capsule (Fig. 2C). Other malignant features such as hemorrhage, necrosis, and vascular infiltration were also observed (fig. 2E-H). The immunohistochemistry was positive for inhibin (Fig. 2I), calretinin, and melan-A. Reinke crystals characteristic of Leydig cell tumors were not found. Based on these findings, the tumor was diagnosed as a malignant right ovarian primary SCT-NOS.

Three courses of bleomycin, etoposide, and cisplatin (bleomycin: $15 \mathrm{mg} / \mathrm{m}^{2}$ on day 1 , etoposide: $100 \mathrm{mg} / \mathrm{m}^{2}$ on days $1-5$, and cisplatin: $20 \mathrm{mg} / \mathrm{m}^{2}$ on days $1-5$ ) were administered as postoperative chemotherapy. Postoperatively, her testosterone immediately decreased to undetectable levels. The patient suffered from persistent fatigue and appetite-loss after the first-course chemotherapy. Endocrinological blood test revealed adrenocortical hypofunction, and hydrocortisone replacement therapy was administered. Three planned courses of chemotherapy were completed without any further complications.

At the time of publication, 4 months after treatment, the patient has been without tumor recurrence in outpatient follow-up. Signs of virilization and Cushing's syndrome have gradually disappeared. Her height growth rate has slowed after the treatment. Although adrenal insufficiency persists, her adrenocorticotropic hormone levels are gradually recovering. She is expected to recover complete self-production of cortisol in the near future. 

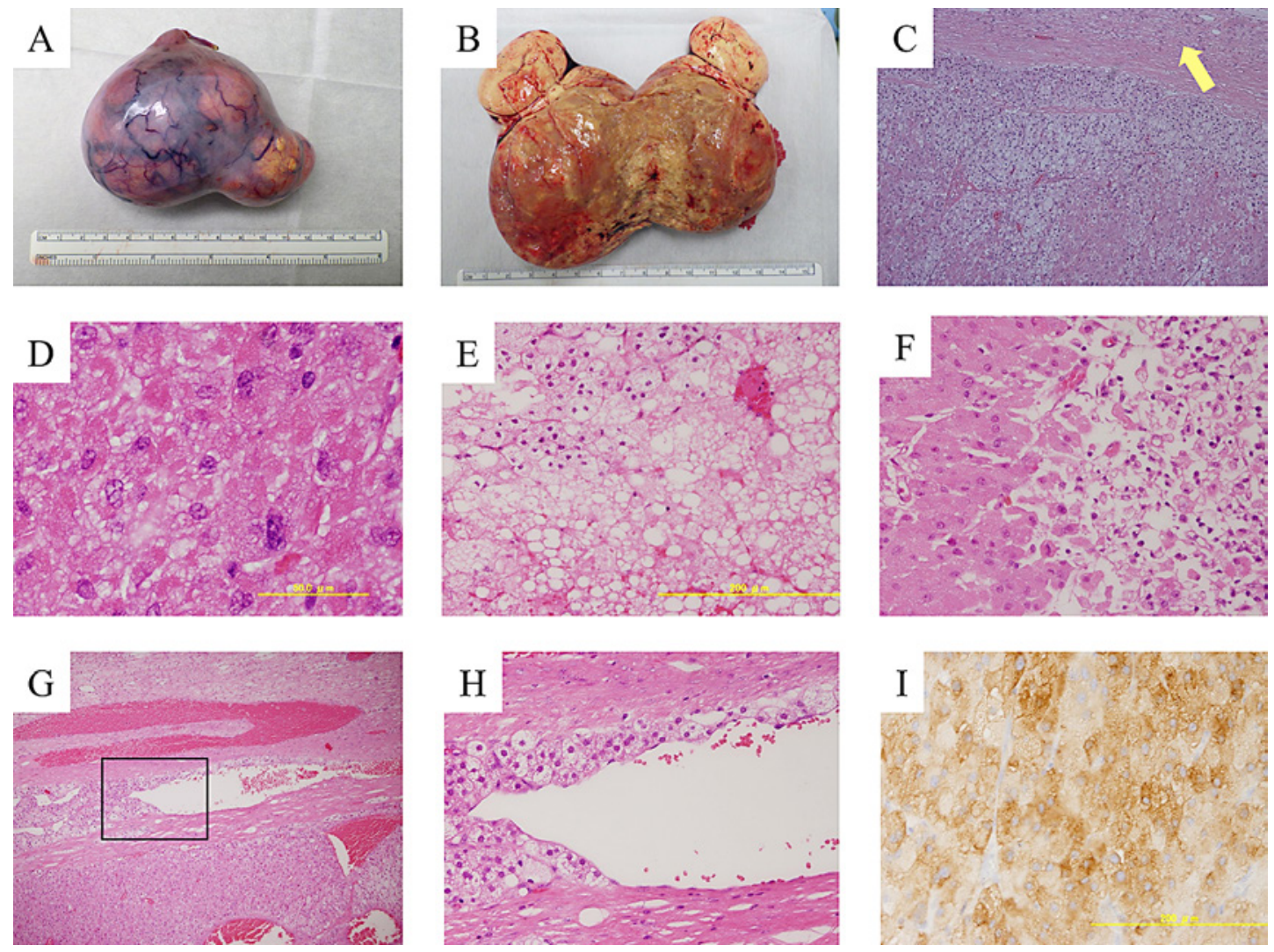

Fig. 2. Gross appearance and pathological findings of the steroid cell tumor. Tumor surface was smooth and white without adhesion to surrounding area (A). Cut surface showed a monotonous yellow fat-rich appearance (B). The tumor was composed of both eosinophilic and vacuolated cytoplasm. Tumor cell infiltration into the capsule (arrow) was observed (C). Tumor cells showed spontaneous severe nuclear atypia (D). Tumor hemorrhage (E) and necrosis (F) were observed. Venous infiltration of tumor cells was observed (G, H). Inhibin-positive cells were demonstrated by brown color on immunostaining (I). Original magnification, $\times 10$ in $\mathbf{C}, \mathbf{G} ; \times 40$ in $\mathbf{E}, \mathbf{F}, \mathbf{H}$, and $\mathbf{I} ; \times 100$ in $\mathbf{D}$.

\section{Discussion}

This case report describes the rare case of a 4-year-old girl with SCT-NOS. Steroid cell tumors of the ovary account for $0.1 \%$ of all ovarian tumors [2]. SCT-NOS is a subtype of steroid cell tumors with undefined cell lineage and cannot be categorized as either a stromal luteoma or Leydig cell tumor. The differential diagnosis for pediatric ovarian tumors includes mature and immature teratomas, germ cell tumors, cystadenomas, and yolk sac tumors. Most pediatric ovarian tumors are mature teratomas, which have a wide spectrum of radiological presentation ranging from purely cystic masses to complex cystic masses with a considerable solid component, keratinoid material, hair, and tooth/calcification [12]. Mature teratoma is predictable due to its characteristic imaging findings, while a uniform inner structure suggests a malignant neoplasm such as immature teratoma or germ cell tumor.

We reviewed pediatric SCT-NOS cases ( $\leq 16$ years) available in published papers (Table 1 ). Most pediatric SCT-NOS cases were found according to various symptoms which depended on the kinds of hormones secreted from the steroid cell tumor. 
Table 1. Summary of reported pediatric cases with ovarian steroid cell tumor, not otherwise specified

\begin{tabular}{|c|c|c|c|c|c|}
\hline Author (year) & $\begin{array}{l}\text { Age, } \\
\text { years }\end{array}$ & $\begin{array}{l}\text { Tumor } \\
\text { size, cm }\end{array}$ & $\begin{array}{l}\text { Clinical presentation } \\
\text { Secreted hormone }\end{array}$ & Treatment & Outcome \\
\hline $\begin{array}{l}\text { Hayes and Scully } \\
\text { (1987) [2] }\end{array}$ & $\begin{array}{l}2-15 \\
(3 \text { cases })\end{array}$ & NA & NA & NA & $\begin{array}{l}\text { No } \\
\text { recurrence }\end{array}$ \\
\hline $\begin{array}{l}\text { Harris et al. } \\
\text { (1991) [3] }\end{array}$ & 8 & $3.5 \times 3.5 \times 2.0$ & $\begin{array}{l}\text { Progressive virilization } \\
\text { Testosterone, androstenedione, } \\
\text { progesterone }\end{array}$ & $\begin{array}{l}\text { Observed after surgery } \\
\text { Salpingo-oophorectomy }\end{array}$ & $\begin{array}{l}\text { No } \\
\text { recurrence }\end{array}$ \\
\hline $\begin{array}{l}\text { Ding and Hsu } \\
\text { (2007) [4] }\end{array}$ & 16 & $5.7 \times 6.3 \times 5.5$ & $\begin{array}{l}\text { Amenorrhea, virilization } \\
\text { Testosterone, androstenedione }\end{array}$ & $\begin{array}{l}\text { Observed after surgery } \\
\text { Laparoscopic cystectomy }\end{array}$ & $\begin{array}{l}\text { No } \\
\text { recurrence }\end{array}$ \\
\hline $\begin{array}{l}\text { Gupta et al. } \\
(2008)[5]\end{array}$ & 5 & NA & $\begin{array}{l}\text { Cushing syndrome } \\
\text { Cortisol, testosterone, progesterone, } \\
\text { estrogen }\end{array}$ & $\begin{array}{l}\text { Observed after surgery } \\
\text { NA }\end{array}$ & NA \\
\hline $\begin{array}{l}\text { Sawathiparnich } \\
\text { et al. (2009) [6] }\end{array}$ & 6 & $7 \times 6 \times 5$ & $\begin{array}{l}\text { Cushing syndrome } \\
\text { Adrenocorticotropic hormone, cortisol, } \\
\text { testosterone, androstenedione }\end{array}$ & $\begin{array}{l}\text { Observed after surgery } \\
\text { Salpingo-oophorectomy }\end{array}$ & $\begin{array}{l}\text { No } \\
\text { recurrence }\end{array}$ \\
\hline $\begin{array}{l}\text { Lee et al. } \\
\text { (2011) [7] }\end{array}$ & 8 & $5.1 \times 4.0$ & $\begin{array}{l}\text { Hypertension, vaginal spotting } \\
\text { Renin, progesterone }\end{array}$ & $\begin{array}{l}\text { Observed after surgery } \\
\text { Salpingo-oophorectomy }\end{array}$ & $\begin{array}{l}\text { No } \\
\text { recurrence }\end{array}$ \\
\hline $\begin{array}{l}\text { Boyraz et al. } \\
\text { (2013) [8] }\end{array}$ & 16 & 6 & $\begin{array}{l}\text { Amenorrhea, virilization } \\
\text { Testosterone }\end{array}$ & $\begin{array}{l}\text { Observed after surgery } \\
\text { Salpingo-oophorectomy }\end{array}$ & $\begin{array}{l}\text { No } \\
\text { recurrence }\end{array}$ \\
\hline $\begin{array}{l}\text { Yılmaz-Ağladıoğlu } \\
\text { et al. (2013) [9] }\end{array}$ & 13 & $2.3 \times 2.2$ & $\begin{array}{l}\text { Progressive virilization } \\
\text { Testosterone, 17-hydroxyprogesterone }\end{array}$ & $\begin{array}{l}\text { Observed after surgery } \\
\text { Salpingo-oophorectomy }\end{array}$ & $\begin{array}{l}\text { No } \\
\text { recurrence }\end{array}$ \\
\hline $\begin{array}{l}\text { Haroon et al. } \\
\text { (2015) [10] }\end{array}$ & 3 & 7.0 & $\begin{array}{l}\text { Irregular vaginal bleeding, gynecomastia } \\
\mathrm{NA}\end{array}$ & $\begin{array}{l}\text { Observed after surgery } \\
\text { Salpingo-oophorectomy }\end{array}$ & $\begin{array}{l}\text { No } \\
\text { recurrence }\end{array}$ \\
\hline $\begin{array}{l}\text { Qian et al. } \\
\text { (2016) [11] }\end{array}$ & 5 & $8.5 \times 4.5 \times 7.3$ & $\begin{array}{l}\text { Vomiting, stomach ache } \\
\text { None }\end{array}$ & $\begin{array}{l}\text { Observed after surgery } \\
\text { Salpingo-oophorectomy }\end{array}$ & $\begin{array}{l}\text { No } \\
\text { recurrence }\end{array}$ \\
\hline $\begin{array}{l}\text { Present case } \\
(2019)\end{array}$ & 4 & $8.0 \times 5.0 \times 5.0$ & $\begin{array}{l}\text { Progressive virilization, Cushing } \\
\text { syndrome }\end{array}$ & $\begin{array}{l}\text { Chemotherapy after surgery } \\
\text { Salpingo-oophorectomy }\end{array}$ & $\begin{array}{l}\text { No } \\
\text { recurrence }\end{array}$ \\
\hline
\end{tabular}

NA, not available.

Testosterone production is typical of SCT-NOS, with hirsutism and virilization being the most common symptoms. Among the 9 cases with available data that we reviewed, serum testosterone levels were increased in 4 cases and virilization was observed in 3 cases. Progressive virilization before puberty emerges as height growth, clitoromegaly, and hoarseness. An elevation of the testosterone levels $>200 \mathrm{ng} / \mathrm{dL}$ is an important diagnostic threshold for discriminating androgen-secreting tumors from non-neoplastic lesions. These clinical characteristics are consistent with our case. Two cases were also associated with Cushing's syndrome. Furthermore, tumoral secretion of estradiol occurred in 2 cases and renin/progesterone in 1, while the other cases were nonfunctional. None of the cases were complicated with ovarian torsion at diagnosis. All previously known SCT-NOS cases in the pediatric age group were benign.

Surgical resection is the primary treatment for ovarian steroid cell tumors. First, histology and grade of malignancy is predicted in analogy to clinical presentation, imaging testing, and blood testing targeting hormones and tumor markers. Then, the provisional surgical form is determined with consideration of patient fertility preservation. In children and adolescents with an ovarian localized tumor, unilateral salpingo-oophorectomy is adequate to preserve 
fertility. Peritoneal dissemination, capsule rupture, and the result of ascites should be checked to determine the final operative procedure. While occasionally seen in nests and columns, microscopic findings of SCT-NOS generally show neoplastic cells arranged in a diffuse pattern. Neoplastic cells are round or polygonal in shape and medium-to-large in size with distinct cell borders. The cytoplasm of the cells has two basic types, eosinophilic granular cytoplasm and vacuolated cytoplasm, which is often for fat stains [2]. Leydig cell tumors should be discriminated from SCT-NOS. Reinke crystals in the cytoplasm is a hallmark of Leydig cell tumors, while they are absent in SCT-NOS.

Although steroid cell tumors are generally unilateral and benign, post-operative chemotherapy is recommended when the case has residual disease after operation or malignant character on pathological examination. In a study analyzing the clinical and pathological features of 63 steroid cell tumors, (i) 2 or more mitoses per $10 \mathrm{HPF}$, (ii) a tumor diameter of $>7 \mathrm{~cm}$, (iii) necrosis, (iv) hemorrhage, and (v) grade 2 or 3 nuclear atypia were identified as pathological features associated with malignant behavior [2]. In the present case, histopathological study revealed 4 out of 5 malignant features: an $8.5 \mathrm{~cm}$-sized unilateral mass with necrosis, hemorrhage, and 3 mitoses per $10 \mathrm{HPF}$. Therefore, we decided to administer three courses of BEP as post-operative chemotherapy. Among the reported cases, this is the first pediatric SCT-NOS case harboring bad prognostic (malignant) pathological features.

There is no strong consensus on adjuvant chemotherapy for malignant SCT-NOS due to the rarity of this kind of tumor. Several combinations of cytotoxic agents have been used, and available evidence suggests that cisplatin alone or in combination with etoposide has some activity in sex-cord stromal tumors. The Gynecologic Oncology Group has shown BEP to be effective as a first-line treatment for malignant ovarian stromal tumors. In patients with stage II primary ovarian stromal tumors or recurrent disease, $69 \%$ were free of disease after 4 cycles of BEP. In another clinical phase II study, the therapeutic activity of a modified PVB regimen (cisplatin, vinblastine, and bleomycin) was confirmed with 7 and 6 patients having complete and partial responses (response rate: 52\%), respectively, among 38 adult patients with advanced or recurrent, pure granulosa cell tumors or mixed granulosa-theca cell tumors (GTCTs). Only the TGM-95 study reported prospective treatment results for rare sex-cord stromal tumors in children. Thirty-eight children with sex-cord stromal tumors were registered and received primary gonadal resection where feasible. Out of 15 patients with disseminated disease or an incomplete resection, 11 patients received VIP chemotherapy (etoposide, ifosfamide, and cisplatin) and did not relapse. With a median follow-up of 5.9 years, the 5-year event-free survival and overall survival rates of 38 patients were 85 and 94\%, respectively [13]. Testosterone levels can be monitored for disease progression or recurrence.

In this case, central adrenocortical hypofunction occurred after tumor resection. Chronic cortisol released from SCT-NOS induces poor response of the pituitary-hypothalamicadrenal axis. The adrenal glands themselves seemed to be intact, because the primary ovarian tumor caused Cushing's syndrome. Restoration of normal adrenal function is expected with time. Hydrocortisone replacement therapy has continued with the intention to carefully taper off after checking insulin tolerance test result. Early-stage detection of testosterone-producing tumors in children leads to bone age acceleration avoidance and improvement in final height.

In conclusion, we experienced the rare case of a 4-year-old girl suffering from progressive virilization and Cushing's syndrome induced by ovarian steroid cell tumor. SCT-NOS are rare ovarian neoplasms but should be considered in patients who present with hirsutism and elevated testosterone levels. Although SCT-NOS in childhood are usually benign, physicians should check the details of pathological findings after surgery due to the possibility of malignancy. In cases of cortisol-producing SCT-NOS, careful follow-up of cortisol levels is critical to avoid shock induced by acute adrenal insufficiency. 
Yoshimatsu et al.: Malignant Ovarian Steroid Cell Tumor NOS in a 4-Year-Old Girl

\section{Statement of Ethics}

Informed consent was obtained from the patient's parents for the treatment and publication of this case. The patient received treatment based on the chemotherapy protocol approved by our institutional protocol committee.

\section{Disclosure Statement}

The authors have no conflicts of interest to declare.

\section{Funding Sources}

The authors did not receive any funding.

\section{Author Contributions}

T.Y. and K.N. were mainly in charge of the patient and administered post-operative chemotherapy; K.O. and J.H. evaluated the endocrine symptoms and replaced hormone for the patient; R.M., K.M., F.O., H.T., M.E-I., and M.E. discussed the therapeutic strategy; J.K. and T.K. enucleated the ovarian tumor; R.K., M.K., and M.F. pathologically diagnosed the tumor as SCT-NOS; T.Y. and K.N. drafted the manuscript; M.E. directed the study and revised the manuscript.

\section{References}

1 Breen JL, Maxson WS. Ovarian tumors in children and adolescents. Clin Obstet Gynecol. 1977;20(3):607-23.

2 Hayes MC, Scully RE. Ovarian steroid cell tumors (not otherwise specified). A clinicopathological analysis of 63 cases. Am J Surg Pathol. 1987;11(11):835-45.

3 Harris AC, Wakely PE Jr, Kaplowitz PB, Lovinger RD. Steroid cell tumor of the ovary in a child. Arch Pathol Lab Med. 1991;115(2):150-4

4 Ding DC, Hsu S. Lipid cell tumor in an adolescent girl: a case report. J Reprod Med. 2007;52(10):956-8.

5 Gupta P, Goyal S, Gonzalez-Mendoza LE, Novisiki N, Vezmar M, Brathwaite CD, et al. Corticotropin-independent cushing syndrome in a child with an ovarian tumor misdiagnosed as nonclassic congenital adrenal hyperplasia. Endocr Pract. 2008;14(7):875-9.

6 Sawathiparnich P, Sitthinamsuwan P, Sanpakit K, Laohapensang M, Chuangsuwanich T. Cushing's syndrome caused by an ACTH-producing ovarian steroid cell tumor, NOS, in a prepubertal girl. Endocrine. 2009; 35(2):132-5.

7 Lee SH, Kang MS, Lee GS, Chung WY. Refractory hypertension and isosexual pseudoprecocious puberty associated with renin-secreting ovarian steroid cell tumor in a girl. J Korean Med Sci. 2011;26(6):836-8.

8 Boyraz G, Selcuk I, Yusifli Z, Usubutun A, Gunalp S. Steroid cell tumor of the ovary in an adolescent: a rare case report. Case Rep Med. 2013;2013:527698.

9 Yılmaz-Ağladıŏglu S, Savaş-Erdeve Ş, Boduroğlu E, Önder A, Karaman İ, Çetinkaya S, et al. A girl with steroid cell ovarian tumor misdiagnosed as non-classical congenital adrenal hyperplasia. Turk J Pediatr. 2013; 55(4):443-6.

10 Haroon S, Idrees R, Fatima S, Memon A, Kayani N. Ovarian steroid cell tumor, not otherwise specified: a clinicopathological and immunohistochemical experience of 12 cases. J Obstet Gynaecol Res. 2015;41(3):424-31.

11 Qian L, Shen Z, Zhang X, Wu D, Zhou Y. Ovarian steroid cell tumor, not otherwise specified: a case report and literature review. Mol Clin Oncol. 2016;5(6):839-41.

12 Sahin H, Abdullazade S, Sanci M. Mature cystic teratoma of the ovary: a cutting-edge overview on imaging features. Insights Imaging. 2017;8(2):227-41.

13 Fresneau B, Orbach D, Faure-Conter C, Verité C, Castex MP, Kalfa N, et al. Sex-cord stromal tumors in children and teenagers: results of the TGM-95 study. Pediatr Blood Cancer. 2015;62(12):2114-9. 